|l $\begin{aligned} & \text { Jurnal Eksplorasi Akuntansi } \\ & \text { Vol. 1, No 2, Seri C, Mei 2019, Hal 769-780 }\end{aligned}$
ISSN : 2656-3649 (Online)

http://jea.ppj.unp.ac.id/index.php/jea/issue/view/7

\title{
PENGARUH KUALITAS INFORMASI AKUNTANSI DAN PERSEPSI KONTROL PERILAKU TERHADAP INTENSI INVESTOR DALAM PEMILIHAN SAHAM
}

\author{
Putri Aisyah $^{1}$, Erinos N.R ${ }^{2}$, Erly Mulyani ${ }^{3}$ \\ 1)Alumni Jurusan Akuntansi Fakultas Ekonomi Universitas Negeri Padang \\ ${ }^{2,3)}$ Jurusan Akuntansi Fakultas Ekonomi Universitas Negeri Padang \\ *Korespondensi: putry.aisyah55@gmail.com
}

\begin{abstract}
This study aims to determine the effect of the quality of accounting information and perceptions of behavioral control on investor intentions in stock selection. The population of this study is the GI-IDX of Higher Education in the City of Padang. Samples taken based on purposive sampling technique using questionnaires as many as 100 respondents obtained by using Slovin formula. The method of analysis is done using Multiple Linear Regression Analysis. The results showed that the quality of accounting information has a positive and significant effect on investor intentions in stock selection and behavior control perceptions have a positive and significant effect on investor intentions in stock selection.
\end{abstract}

Keywords: Quality of Accounting Information, Perception of Behavior Control, Investor Intention in Stock Selection.

\section{How to cite (APA 6thstyle)}

Aisyah, P., N.R, Erinos,. \& Mulyani, E. (2019). Pengaruh Kualitas Informasi Akuntansi Dan Persepsi Kontrol Perilaku Terhadap Intensi Investor Dalam Pemilihan Saham. Jurnal Eksplorasi Akuntansi, 1(2), Seri C, 769-780.

\section{PENDAHULUAN}

Di era globalisasi seperti saat ini sangat menarik untuk membahas dunia investasi dan pasar modal. Investasi dan pasar modal sudah menjadi bagian dari fundamental ekonomi baik itu di negara maju maupun di negara berkembang. Indonesia adalah salah satu negara berkembang yang mempunyai kekuatan baru di sektor investasi dan pasar modal. Hal itu dibuktikan dengan pengamatan terhadap fluktuasi Indeks Harga Saham Gabungan (IHSG) di BEI. Penelitian yang dilakukan Anggraiawan (2017) dan Zhou (2014) menemukan bahwa intensi investor dalam pemilihan saham yang dipengaruhi oleh kualitas informasi akuntansi dan persepsi kontrol perilaku memiliki hubungan positif dan signifikan. Penelitian yang dilakukan Masrurun (2015) berbanding terbalik dengan penelitian Anggraiawan (2017) yang menemukan bahwa persepsi kontrol perilaku berpengaruh negatif terhadap intensi investor dalam pemilihan saham. Untuk melakukan sebuah investasi dipengaruhi oleh beberapa faktor salah satunya adalah modal atau dana. 
Intensi dalam investasi merupakan proses kognitif untuk melakukan estimasi terhadap risk dan return. Bentuk sikap tersebut didukung oleh tiga faktor, yaitu: pertama, determination, Kedua, self dicipline, Ketiga, fighting. Nofsinger, 2005 menyatakan bahwa Intensi investor dalam saham memerlukan pengetahuan analisis khusus untuk meyakini tentang kinerja saham yang akan dipilih dalam investasi saham secara keseluruhan. Tujuan investor melakukan kegiatan investasi ialah untuk memperoleh pendapatan atau tingkat pengembalian investasi (return) yang akan diterima di masa depan.

Informasi akuntansi sebagai salah satu basis informasi dalam pengambilan keputusan investasi, merupakan kandungan internal yang dapat diperoleh dari laporan keuangan perusahaan melalui teknik analisis fundamental. Keputusan investasi yang dimaksud adalah keputusan untuk membeli, menjual, atau pun mempertahankan kepemilikan saham. Pengambilan keputusan dalam investasi dilihat dari Informasi akuntansi yang terdapat dalam laporan keuangan yang berkualitas.

Faktor lain yang dapat mempengaruhi intensi investor selain faktor informasi akuntansi adalah persepsi kontrol prilaku. Menurut Ajzen (1991) persepsi kontrol perilaku (perceived behavioral control), yaitu keyakinan bahwa seorang individu pernah melaksanakan perilaku tertentu, individu memiliki fasilitas dan waktu untuk melakukan perilaku itu, kemudian individu melakukan estimasi atas kemampuan dirinya apakah dia punya kemampuan atau tidak memiliki kemampuan untuk melaksanakan perilaku itu. Persepsi kontrol perilaku memiliki pengaruh terhadap intensi investor dalam pemilihan saham.

\section{REVIU LITERATUR DAN HIPOTESIS Theory of Planned Behavior}

Teori ini merupakan pengembangan dari teori sebelumnya yaitu Theory of Reasoned Action yang dikemukakan pertama kali oleh Ajzen (1991). Teori ini merupakan teori tindakan yang beralasan. Theory of Planned Behavior juga dikembangkan untuk memprediksi perilaku-perilaku yang sepenuhnya tidak di bawah kendali individu. Theory of Planned Behavior didasarkan pada asumsi bahwa manusia adalah makhluk yang rasional dan menggunakan informasi-informasi yang mungkin baginya secara sistematis, orang memikirkan implikasi dari tindakan mereka sebelum mereka memutuskan untuk melakukan atau tidak melakukan perilaku tertentu.

\section{Intensi Investor dalam Pemilihan Saham}

Intensi dalam berinvestasi memerlukan pengetahuan analisis khusus untuk meyakini tentang kinerja saham yang akan dipilih dalam investasi saham secara keseluruhan (Hartono, 2007). Intensi berkaitan erat dengan pengetahuan dan sikap seseorang terhadap sesuatu hal, serta dengan perilaku itu sendiri sebagai perwujudan dari intensinya.

\section{Kualitas Informasi Akuntansi}

Informasi akuntansi yang bermanfaat harus mempunyai kualitas informasi relevan dan reliabel. Karakteristik kualitas informasi akuntansi menunjukkan laporan keuangan harus memiliki nilainilai sebagai berikut: (a) Kualitas Primer. (b) Kualitas Sekunder. (c) Keterbatasan Laporan Keuangan. 


\section{Persepsi Kontrol Perilaku}

Persepsi kontrol perilaku secara konseptual diharapkan untuk memperkuat pengaruh intensi pada perilaku yang dilakukan individu, sehingga suatu intensi yang kuat akan menghasilkan perilaku hanya jika persepsi kontrol perilaku yang dimiliki individu juga kuat. Menurut Wijaya (2007) kontrol perilaku merupakan persepsi terhadap kekuatan faktor-faktor yang mempermudah atau mempersulit.

\section{Hubungan Kualitas Informasi Akuntansi terhadap Intensi Investor dalam Pemilihan Saham}

Maslichah (2014) menunjukkan bahwa informasi akuntansi merupakan kinerja laporan keuangan sebagai signal good news. Bentuk informasi keuangan salah satunya adalah informasi akuntansi dalam bentuk laporan keuangan. Dapat disimpulkan bahwa hipotesis pertama yaitu:

H1: Kualitas informasi akuntansi berpengaruh positif terhadap intensi investor dalam pemilihan saham.

\section{Hubungan Persepsi Kontrol Perilaku terhadap Intensi Investor dalam Pemilihan Saham} Menurut Wijaya (2007) persepsi kontrol perilaku merupakan persepsi terhadap kekuatan faktorfaktor yang mempermudah atau mempersulit. Anggraiawan (2017) menunjukkan bahwa persepsi kontrol perilaku berpengaruh signifikan terhadap intensi dalam pemilihan saham. Dapat disimpulkan bahwa hipotesis kedua yaitu:

H2: Persepsi kontrol perilaku berpengaruh positif terhadap intensi investor dalam pemilihan saham.

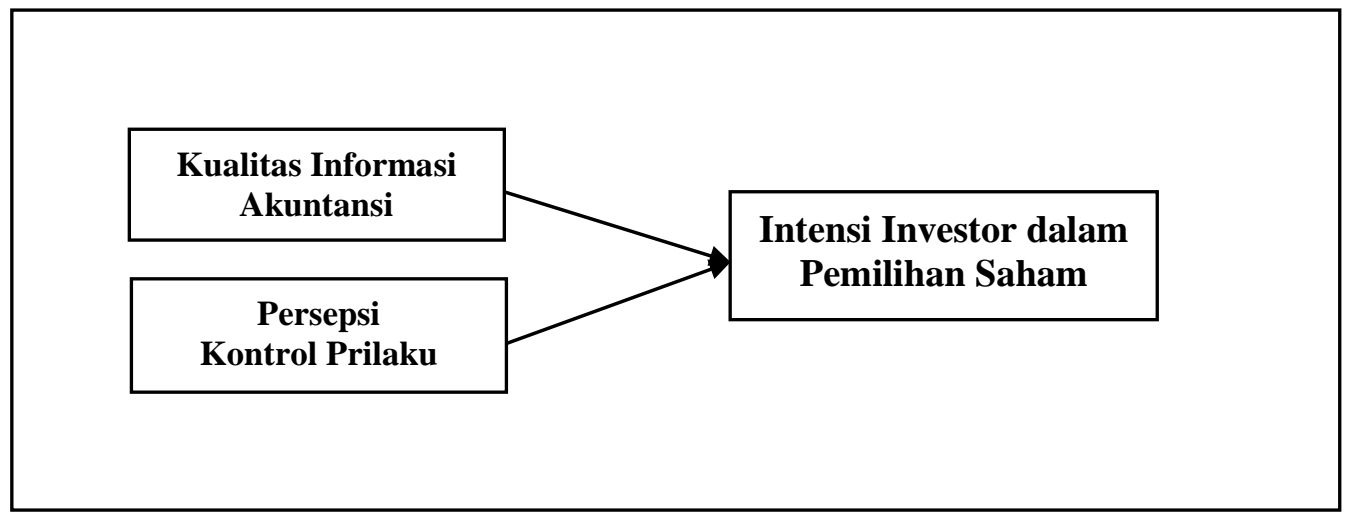

Gambar 1.

Kerangka Konseptual

\section{METODE PENELITIAN}

\section{Jenis Penelitian}

Penelitian ini adalah penelitian kausatif. Tujuan penelitian kausatif untuk mengetahui pengaruh variabel independen terhadap variabel dependen, pada penelitian ini peneliti ingin menguji pengaruh kualitas informasi akuntansi dan persepsi kontrol perilaku (variabel independen) terhadap intensi dalam pemilihan saham saham (variabel dependen).

\section{Populasi dan Sampel}

Populasi dalam penelitian ini adalah pada GI-BEI Perguruan Tinggi yang ada di Kota Padang. Jumlah populasi dalam penelitian ini adalah sebanyak 4669 investor, sehingga presentase 
kelonggaran yang digunakan adalah $10 \%$ dan hasil perhitungan dapat dibulatkan untuk mencapai kesesuaian. sampel yang menjadi responden dalam penelitian ini digenapkan 100 orang pada GIBEI Perguruan Tinggi yang ada di Kota Padang.

\section{Jenis Dan Teknik Pengumpulan Data}

Jenis data dalam penelitian ini adalah data subjek. Sumber data dalam penelitian ini adalah data primer. Teknik pengumpulan data adalah melalui menyebarkan kuesioner kepada kepada investor yang aktif di GI-BEI Perguruan Tinggi yang ada di Kota Padang yang berjumlah 100 orang dari 5 (lima) GI-BEI Perguruan Tinggi di Kota Padang.

\section{Instrumen Variabel Penelitian}

1. Intensi Investor dalam Pemilihan Saham Intensi dalam investasi merupakan proses kognitif untuk melakukan estimasi terhadap risk dan return.

2. Kualitas Informasi Akuntansi

SFAC No 2 menyatakan kualitas yang membedakan informasi berguna dari informasi yang kurang berguna adalah relevan dan reliabel.

3. Persepsi Kontrol Perilaku

Persepsi kontrol perilaku (perceived behavioral control), yaitu keyakinan bahwa seorang individu pernah melaksanakan perilaku tertentu, individu memiliki fasilitas dan waktu untuk melakukan perilaku itu, kemudian individu melakukan estimasi atas kemampuan dirinya apakah dia punya kemampuan atau tidak memiliki kemampuan untuk melaksanakan perilaku itu.

\section{Teknik Analisis Data}

\section{Analisis Statistik Deskriptif}

Teknik statistik deskriptif dalam penelitian ini bertujuan untuk menginterpretasikan nilai ratarata, median, standar deviasi, nilai maksimum, dan nilai minimum dari masing-masing variabel penelitian.

\section{Uji Asumsi Klasik \\ Uji Normalitas}

Uji normalitas pada penelitian ini dengan menggunakan uji Kolmogorov-Smirnov. Jika nilai signifikan lebih besar dari nilai alpha (Sig. $>\alpha$ ), maka nilai residual yang telah terstandarisasi pada model regresi berdistribusi normal.

\section{Uji Multikolinearitas}

Uji multikolinearitas dapat dilakukan dengan melihat nilai TOL (Tolerance) dan Variance Inflation Factor (VIF). Jika nilai VIF tidak lebih dari 10, maka model tidak terdapat gejala multikolinearitas. Nilai TOL dan VIF yang menunjukkan adanya gejala multikolinearitas adalah nilai TOL $<0,10$ atau nilai $\mathrm{VIF}>10$.

Uji Heteroskedastisitas

Uji heteroskedastisitas pada penelitian ini dengan menggunakan metode Glejser. Jika nilai signifikan lebih besar dari nilai alpha (Sig. $>\alpha$ ), maka dapat dipastikan model tidak mengandung gejala heteroskedastisitas atau dikatakan tidak terjadi heteroskedastisitas apabila $\mathrm{t}$ hitung $<\mathrm{t}$ tabel. 


\section{Analisis Regresi Linier Berganda}

Model regresi berganda yang digunakan dalam penelitian ini:

Keterangan:

$$
I=\alpha+\beta_{1} K+\beta_{2} P K P+e
$$

$\alpha$ : Konstanta

$\beta$ : Koefisien regresi

I : Intensi dalam Pemilihan Saham

$\mathrm{K}$ : Kualitas Informasi Akuntansi

PKP: Persepsi Kontrol Prilaku

e : Error

\section{Uji Kelayakan Model}

\section{Uji $\mathbf{R}^{2}$ atau Koefisien Determinasi}

Koefisien determinasi $\left(\mathrm{R}^{2}\right)$ digunakan untuk mengukur seberapa jauh kemampuan sebuah model dalam menerangkan variabel dependen atau melihat besar peran variabel independen terhadap variabel dependen. Nilai koefisien determinasi berkisar antara 0-1.

\section{Uji F (Simultan)}

Uji statistik F dilakukan untuk menguji kelayakan model (goodness of fit) yang digunakan dalam analisis regresi. Uji F yaitu uji bersama-sama variabel independen terhadap variabel dependen. Tingkat kepercayaan untuk pengujian hipotesis adalah $95 \%$ atau $(\alpha)=5 \%$.

\section{Uji Hipotesis (t)}

Uji statistik t menunjukkan seberapa jauh pengaruh masing -masing variabel independen secara individu dalam menerangkan variasi variabel dependen. Pada uji ini, nilai t hitung akan dibandingkan nilai $t$ yang terdapat pada tabel : (a) Bila $t$ hitung $>t$ tabel atau tingkat signifikansi (Sig $\leq 0,05)$, maka $\mathrm{H}_{\mathrm{a}}$ diterima dan $\mathrm{H}_{\mathrm{o}}$ ditolak, variabel independen berpengaruh terhadap variabel dependen. (b) Bila $t$ hitung $<\mathrm{t}$ tabel atau probabilitas $>$ tingkat signifikansi $(\mathrm{Sig} \geq 0,05)$, maka $\mathrm{H}_{\mathrm{a}}$ ditolak dan $\mathrm{H}_{\mathrm{o}}$ diterima, variabel independen tidak berpengaruh terhadap variabel dependen.

\section{HASIL DAN PEMBAHASAN}

Populasi dalam penelitian ini adalah pada GI-BEI Perguruan Tinggi yang ada di Kota Padang. Jumlah populasi dalam penelitian ini adalah sebanyak 4.669 investor, sehingga presentase kelonggaran yang digunakan adalah $10 \%$ dan hasil perhitungan dapat dibulatkan untuk mencapai kesesuaian. Maka untuk mengetahui sampel penelitian, dengan perhitungan menggunakan rumus Slovin sebagai berikut:

$$
n=\frac{N}{1+N(e)^{2}}=97,69 ;(\text { digenapkan } 100)
$$

\section{Uji Asumsi Klasik}

Berdasarkan data yang telah dikumpulkan, kemudian dilakukan analisis untuk pernyataan penelitian dalam melakukan analisis menggunakan teknik regresi berganda. Sebelum data diolah dengan regresi berganda maka dilakukan uji asumsi klasik untuk memperoleh keyakinan bahwa data yang diperoleh beserta variabel penelitian layak diolah lebih lanjut. Uji asumsi klasik yang dilakukan terdiri dari: 


\section{Uji Normalitas}

Uji normalitas digunakan untuk menguji apakah distribusi data mengikuti atau mendekati distribusi normal, data yang baik adalah data yang pola distribusinya normal. Uji normalitas dapat dilakukan dengan metode Kolmogorav-Smirnov test terdapat pada tabel 10 sebagai berikut.

\section{Tabel 1}

\section{Uji Normalitas}

\begin{tabular}{lll}
\hline \multicolumn{3}{c}{ One-Sample Kolmogorov-Smirnov Test } \\
\hline & \multicolumn{1}{c}{ Unstandardized Residual } \\
\hline $\mathrm{N}$ & 100 \\
\hline \multirow{2}{*}{ Normal Parameters ${ }^{\mathrm{a}, \mathrm{b}}$} & Mean & 0,0000000 \\
\cline { 2 - 3 } & Std. Deviation & 2,76532554 \\
\multirow{2}{*}{$\begin{array}{l}\text { Most Extreme } \\
\text { Differences }\end{array}$} & Absolute & 0,081 \\
\cline { 2 - 3 } & Positive & 0,081 \\
\cline { 2 - 2 } Kolmogorov-Smirnov $\mathrm{Z}$ & Negative & $-0,053$ \\
\hline Asymp. Sig. (2-tailed) & 0,808 \\
\hline a. Test distribution is Normal. & 0,532 \\
\hline b. Calculated from data. \\
\hline
\end{tabular}

Berdasarkan tabel 10 di atas terlihat bahwa hasil uji normalitas menunjukkan level signifikasi lebih besar dari $\alpha(\alpha=0,05)$ yaitu $0,532>0,05$ yang berarti bahwa data terdistribusi secara normal.

\section{Uji Multikolinearitas}

Tabel 2.

\section{Uji Multikolinearitas}

\section{Coefficients $^{\mathrm{a}}$}

\begin{tabular}{llll}
\hline \multirow{2}{*}{ Model } & \multicolumn{2}{l}{ Collinearity Statistics } \\
\cline { 3 - 4 } & & Tolerance & VIF \\
\hline \multirow{2}{*}{1} & Kualitas Informasi Akuntansi & 0,872 & 1,147 \\
\cline { 2 - 4 } & Persepsi Kontrol Perilaku & 0,872 & 1,147 \\
\hline
\end{tabular}

a. Dependent Variable: Intensi Investor dalam Pemilihan

Saham

Sumber: Data Primer yang diolah tahun 2019

Berdasarkan tabel 11 di atas dapat dilihat variabel kualitas informasi akuntansi dengan nilai (VIF) $1,147<10$ dan tolerance $0,872>0,1$, variabel persepsi kontrol perilaku memiliki nilai (VIF) $1,147<10$ dan tolerance $0,872>0,1$, dengan demikian dapat dikatakan tidak terdapat korelasi variabel-variabel bebas antara satu dengan yang lainnya, atau variabel independen pada penelitian ini bebas dari gejala multikolinearitas.

\section{Uji Heteroskedastisitas}

Pendeteksian adanya heteroskedastisitas pada penelitian ini menggunakan uji Glejser. Pengujian ini membandingkan signifikan dari uji ini apabila hasilnya sig > 0,05 atau 5\%. Jika signifikan di 
atas 5\% maka disimpulkan model regresi tidak mengandung adanya heteroskedastisitas. Hasil pengujian dapat dilihat pada tabel 12 berikut ini:

\section{Tabel 3.}

Uji Heterokedastisitas

Coefficients $^{\mathbf{a}}$

\begin{tabular}{|c|c|c|c|c|c|c|}
\hline \multirow{2}{*}{\multicolumn{2}{|c|}{ Model }} & \multicolumn{2}{|c|}{$\begin{array}{l}\text { Unstandardized } \\
\text { Coefficients }\end{array}$} & \multirow{2}{*}{$\begin{array}{l}\text { Standardized } \\
\text { Coefficients } \\
\text { Beta }\end{array}$} & \multirow[b]{2}{*}{$\mathrm{t}$} & \multirow[b]{2}{*}{ Sig. } \\
\hline & & $\mathrm{B}$ & Std. Error & & & \\
\hline 1 & (Constant) & 3,027 & 2,089 & & 1,449 & 0,150 \\
\hline & $\begin{array}{l}\text { Kualitas } \\
\text { Akuntansi }\end{array}$ & $-0,009$ & 0,038 & $-0,026$ & $-0,236$ & 0,814 \\
\hline & Persepsi Kontrol Perilaku & $-0,022$ & 0,101 & $-0,024$ & $-0,221$ & 0,825 \\
\hline
\end{tabular}

a. Dependent Variable: RES2

Sumber: Data Primer yang diolah tahun 2019

Berdasarkan tabel 3 diatas dapat dilihat bahwa hasil perhitungan masing-masing variabel menunjukkan bahwa level sig. lebih dari 0,05 yaitu 0,814>0,05 untuk variabel kualitas informasi akuntansi, untuk variabel persepsi kontrol perilaku 0,825 >0,05 sehingga penelitian ini bebas dari gejala heterokedastisitas dan layak untuk diteliti.

\section{Teknik Analisis Data}

\section{Analisis Deskriptif}

Berikut ini merupakan deskripsi hasil penelitian pengaruh kualitas informasi akuntansi dan persepsi kontrol perilaku terhadap intensi investor dalam pemilihan saham. Variabel-variabel tersebut dapat dikategorikan dalam bentuk distribusi frekuensi, kemudian dilakukan analisis mean, standar deviasi, tingkat capaian responden serta memberikan interpretasi analisis tersebut.

\section{Analisis Regresi Linier Berganda}

Regresi linear berganda pada dasarnya merupakan perluasan dari regresi linear sederhana yaitu menambah jumlah variabel bebas yang yang sebelumnya hanya satu menjadi dua atau lebih variabel bebas. Alat analisis regresi linear berganda digunakan untuk melihat pengaruh beberapa variabel bebas (independent variable) terhadap variabel terikat (dependent variable). Perhitungan statistik dalam analisis regresi linear berganda yang digunakan dalam penelitian ini adalah dengan menggunakan bantuan program komputer SPSS 21. Ringkasan hasil pengolahan data dengan menggunakan program SPSS 21 tersebut adalah sebagai berikut. 
Tabel 4.

Coefficients $^{\mathbf{a}}$

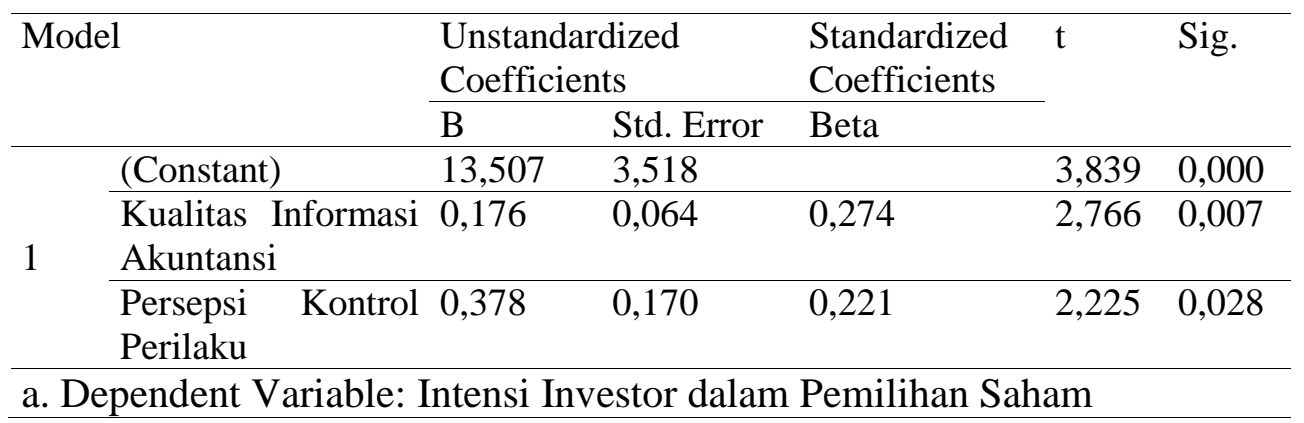

Berdasarkan tabel 17 di atas dapat dianalisis model persamaaan sebagai berikut:

$$
\mathrm{I}=13,507+0,176 \mathrm{~K}+0,378 \mathrm{PKP}+e
$$

Keterangan:

I = Intensi Investor dalam Pemilihan Saham

$\mathrm{K}=$ Kualitas Informasi Akuntansi

$\mathrm{PKP}=$ Persepsi Kontrol Perilaku

\section{Uji Kelayakan Model}

\section{a. Koefisien Determinasi $\mathbf{R}^{2}$}

Tabel 5.

Uji Adjusted $R^{2}$

\begin{tabular}{|c|c|c|c|c|}
\hline \multicolumn{5}{|c|}{ Model Summary } \\
\hline Model & $\mathrm{R}$ & R Square & $\begin{array}{l}\text { Adjusted } \\
\text { Square }\end{array}$ & $\begin{array}{l}\mathrm{R} \text { Std. Error of the } \\
\text { Estimate }\end{array}$ \\
\hline 1 & $0,409^{a}$ & 0,168 & 0,150 & 2,794 \\
\hline
\end{tabular}

a. Predictors: (Constant), Persepsi Kontrol Perilaku, Kualitas Informasi Akuntansi

Sumber : Data primer yang diolah tahun 2019

Berdasarkan tabel $5 \mathrm{di}$ atas besarnya Adjusted $R$ Square adalah 0,150. Hal ini mengidentifikasikan bahwa konstribusi variabel kualitas informasi akuntansi dan persepsi kontrol perilaku terhadap intensi investor dalam pemilihan saham adalah sebesar 15\%, sedangkan $85 \%$ lainnya ditentukan oleh faktor lain di luar model yang tidak terdeteksi dalam penelitian ini.

\section{b. Uji F}

Berdasarkan hasil analisis data yang diperoleh menguji hipotesis ini, maka dilakukan uji $\mathrm{F}$ dengan membandingkan nilai $F_{\text {hitung }}$ dengan $F_{\text {tabel. }}$ Pada level signifikansi 0,05, besar $F_{\text {tabel }}$ untuk $\mathrm{n}=100$ adalah 3,09. Hasil pengolahan statistik analisis regresi menunjukkan nilai $\mathrm{F}=9,759$ dan

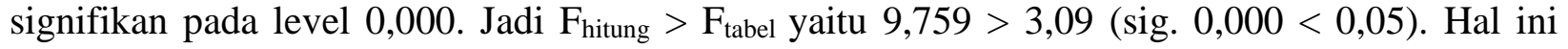
menunjukkan bahwa ada pengaruh secara simultan variabel independen terhadap variabel 
dependen. Hasil analisis data yang diperoleh tentang kualitas informasi akuntansi dan persepsi kontrol perilaku terhadap intensi investor dalam pemilihan saham, Uji F dapat dilihat pada tabel 19 berikut ini.

Tabel 6.

ANOVA ${ }^{a}$

\begin{tabular}{|c|c|c|c|c|c|c|}
\hline \multicolumn{2}{|c|}{ Model } & $\begin{array}{l}\text { Sum } \\
\text { Squares }\end{array}$ & of Df & Mean Square & $\mathrm{F}$ & Sig. \\
\hline \multirow{3}{*}{1} & Regression & 152,334 & 2 & 76,167 & 9,759 & $0,000^{\mathrm{b}}$ \\
\hline & Residual & 757,056 & 97 & 7,805 & & \\
\hline & Total & 909,390 & 99 & & & \\
\hline \multicolumn{7}{|c|}{ a. Dependent Variable: Intensi Investor dalam Pemilihan Saham } \\
\hline \multicolumn{7}{|c|}{$\begin{array}{l}\text { b. Predictors: (Constant), Persepsi Kontrol Perilaku , Kualitas Informasi } \\
\text { Akuntansi }\end{array}$} \\
\hline
\end{tabular}

\section{c. Uji Hipotesis (t-test)}

Uji t statistik (t-test) bertujuan untuk mengetahui hubungan yang signifikan dari masing-masing variabel bebas terhadap variabel terikatnya. Pengujian hipotesis secara parsial dilakukan dengan

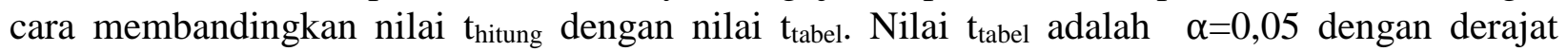
bebas $(\mathrm{db})=\mathrm{n}-\mathrm{k}=100-3=97$ adalah 1,98, berdasarkan hasil analisis pada tabel 6 maka dapat diketahui pengaruh variabel independen secara parsial terhadap variabel dependen adalah sebagai berikut.

\section{Hipotesis 1}

Pengujian hipotesis dilakukan dengan membandingkan $t_{\text {hitung }}$ dengan nilai $t_{\text {tabel }}$. Hipotesis diterima jika $t_{\text {hitung }}>t_{\text {tabel }}$ atau nilai sig. $<0,05$. Nilai $t_{\text {tabel }}$ pada $\alpha=0,05$ adalah 1,98. Variabel kualitas informasi akuntansi (K) nilai thitung adalah 2,766 dan nilai sig. yaitu 0,007 dengan demikian dapat dikatakan bahwa $t_{\text {hitung }}>t_{\text {tabel }}$ yaitu 2,766 > 1,98 atau nilai signifikasi $0,007<$ 0,05. Nilai koefisien $\beta$ dari variabel kualitas informasi akuntansi bernilai positif yaitu 0,176 . Hal ini menunjukkan bahwa penelitian ini dapat membuktikan kualitas informasi akuntansi berpengaruh positif signifikan terhadap intensi investor dalam pemilihan saham (I) dengan demikian hipotesis pertama $\left(\mathrm{H}_{1}\right)$ diterima.

\section{Hipotesis 2}

Pengujian hipotesis dilakukan dengan membandingkan $t_{\text {hitung }}$ dengan nilai $t_{\text {tabel }}$. Hipotesis diterima jika $t_{\text {hitung }}>t_{\text {tabel }}$ atau nilai sig. $<0,05$. Nilai $t_{\text {tabel }}$ pada $\alpha=0,05$ adalah 1,98. Variabel persepsi kontrol perilaku (PKP) nilai thitung adalah 2,225 dan nilai sig. yaitu 0,028 dengan demikian dapat dikatakan bahwa $t_{\text {hitung }}>t_{\text {tabel }}$ yaitu 2,225 >1,98 atau nilai signifikasi $0,028<$ 0,05 . Nilai koefisien $\beta$ dari variabel persepsi kontrol perilaku bernilai positif yaitu 0,378 . Hal ini menunjukkan bahwa penelitian ini dapat membuktikan persepsi kontrol perilaku berpengaruh positif signifikan terhadap intensi investor dalam pemilihan saham (I) dengan demikian hipotesis pertama $\left(\mathrm{H}_{2}\right)$ diterima. 


\section{Pembahasan \\ Pengaruh Kualitas Informasi Akuntansi Terhadap Intensi Investor dalam Pemilihan Saham}

Intensi untuk memilih saham dibentuk dari penyebab perilaku yaitu informasi. Informasi dapat diterima dalam bentuk informasi keuangan maupun informasi non keuangan. Bentuk informasi keuangan salah satunya adalah informasi akuntansi dalam bentuk laporan keuangan. Informasi akuntansi yang ada dalam laporan keuangan harus berkualitas agar dapat merepresentasikan kondisi sesungguhnya tentang kinerja keuangan perusahaan. Informasi yang disediakan dalam laporan keuangan tersebut memiliki tujuan sebagai dasar pertimbangan dalam pengambilan keputusan bisnis bagi para pengguna yang meliputi investor, calon investor, pemberi pinjaman, karyawan, pemasok, kreditur lainnya, pelanggan, pemerintah dan masyarakat.

Hasil ini mendukung penelitian yang telah dilakukan oleh Masrurun (2015) dan Anggraiawan (2017) menunjukkan bahwa kualitas informasi akuntansi berpengaruh signifikan terhadap intensi dalam pemilihan saham. Semakin berkualitas informasi akuntansi, maka akan menunjukkan bahwa perusahaan memiliki keuangan yang sehat. Implikasinya, hal ini akan menjadi keyakinan bagi pengguna untuk memilih saham yang menyediakan informasi akuntansi yang berkualitas.

\section{Pengaruh Persepsi Kontrol Perilaku Terhadap Intensi Investor dalam Pemilihan Saham}

Persepsi kontrol perilaku investor memiliki indikator antara lain keyakinan diri sendiri, dukungan modal, dan dukungan teknologi. Hal ini sejalan dengan konsep planned behavior theory yang mengungkapkan bahwa persepsi kontrol perilaku didasarkan pada keyakinan individu mengenai faktor pendukung dan atau faktor penghambat intensi untuk melakukan suatu perilaku. Keyakinan yang kuat pada diri sendiri, dukungan modal, dan dukungan teknologi akan mendukung tingginya intensi investor untuk memilih suatu saham. Sebaliknya ketika keyakinan investor pada diri sendiri, dukungan modal, dan dukungan teknologi lemah, maka intensi investor untuk memilih saham menjadi rendah.

Hasil ini sejalan dengan penelitian Anggraiawan (2017) menjelaskan bahwa persepsi kontrol perilaku berpengaruh signifikan terhadap intensi dalam pemilihan saham yang menunjukkan bahwa investor mempersepsikan semakin kuat kontrol perilaku, maka semakin tinggi intensi investor untuk memilih saham.

\section{KESIMPULAN, KETERBATASAN, SARAN \\ Kesimpulan}

Berdasarkan hasil penelitian dan pengujian hipotesis yang telah dilaksanakan, maka hasil penelitian dapat disimpulkan bahwa Kualitas informasi akuntansi berpengaruh positif dan signifikan terhadap intensi investor dalam pemilihan saham ini berarti semakin berkualitas informasi akuntansi suatu perusahaan, maka semakin menambah keyakinan investor untuk memilih saham pada investor GI-BEI Perguruan Tinggi di Kota Padang. Persepsi kontrol perilaku berpengaruh positif dan signifikan terhadap intensi investor dalam pemilihan saham ini berarti semakin kuat kontrol perilaku seorang investor maka akan semakin tinggi intensi investor dalam pemilihan saham pada investor GI-BEI Perguruan Tinggi di Kota Padang 


\section{Keterbatasan}

Meskipun peneliti telah berusaha merancang dan mengembangkan penelitian sedemikian rupa, namun masih terdapat beberapa keterbatasan dalam penelitian yaitu:

1. Nilai Adjusted R2 masih tergolong rendah hanya sebesar $15 \%$ ini menunjukkan bahwa masih banyak variabel lain yang memiliki kontribusi besar dalam mempengaruhi intensi investor dalam pemilihan saham.

2. Penelitian ini terbatas pada investor GI-BEI Perguruan Tinggi di Kota Padang sehingga hasil penelitian tidak dapat digeneralisasi untuk investor secara keseluruhan.

\section{Saran}

Berdasarkan kesimpulan dari hasil penelitian yang telah dijelaskan diatas dapat diberikan saran sebagai berikut:

1. Kualitas informasi akuntansi secara langsung berpengaruh terhadap intensi investor dalam pemilihan saham namun masih tergolong rendah, sehingga investor harus lebih memperhatikan informasi apa saja yang bermanfaat dalam laporan keuangan yang dapat membantu dalam pengambilan keputusan saham.

2. Persepsi kontrol perilaku secara langsung berpengaruh terhadap intensi investor dalam pemilihan saham namun masih tergolong rendah, sehingga investor harus yakin pada kekuatan perasaan individu akan setiap faktor pendukung atau penghambat melalui dukungan modal dan teknologi yang diperolehnya.

3. Bagi peneliti selanjutya, hendaknya melakukan penelitian tidak hanya pada investor GI-BEI Perguruan Tinggi di Kota Padang agar hasil yang diperoleh lebih berkualitas, menambah investor yang akan dijadikan sampel penelitian, misalnya seluruh investor yang aktif di Bursa Efek Indonesia (BEI) agar hasil penelitian lebih dapat digeneralisasi.

4. Bagi peneliti selanjutnya diharapkan agar dapat meneliti faktor-faktor lainnya yang berpengaruh terhadap intensi investor dalam pemilihan saham yang belum diteliti pada penelitian ini, seperti norma subjektif, kepercayaan, motivasi, dan lain-lain.

\section{DAFTAR PUSTAKA}

(2006). The theory of planned behavior. Tersedia di http://people.umas.edu/aizen/tpb/html. Diakses pada tanggal 19 Agustus 2018.

(2011). Manfaat Informasi Akuntansi Untuk Memprediksi Risiko Investasi Saham Berdasarkan Pendekatan Decision Usefulness. Disertasi. Surabaya: Universitas Airlangga

Ajzen, I. (1991). Theory of Planned Behavior. Organizational Human Behavior and Human Decission Processes. 50, 179-211.

Anggraiawan, i. A, Isynuwardhana, D. dan Mahardika D. P. K. (2017). Determinan Perilaku Investor Individu dalam Pengambilan Keputusan Investasi Saham pada Investor yang Terdaftar di Gi-Bei Telkom University. e-Proceeding of Management. Vol.4, No.1.

Dayakisni, T. dan Hudaniah. (2012). Psikologi sosial (Ed. revisi). Malang: UMM Press

Fishbein, M. dan Ajzen I. (1975). Belief, attitude, intention, and behavior: an introduction to theory and research. Massachusetts: Addison-Weshley.

Ghozali, I. (2016). Aplikasi Analisis Multivariate Dengan Program IBM SPSS 23. Semarang: Badan Penerbit Universitas Diponegoro. 
Hartono, J. (2007). Sistem Informasi Keperilakuan, Edisi 1. Yogyakarta: Penerbit Andi.

Hartono, J. (2011). Teori Portofolio dan Analisis Investasi. Yogyakarta: BPFE Yogyakarta.

Jian, Z. dan Phan, K. C. (2014). Factors Influencing Individual Investor Behavior: An Empirical Study of the Vietnamese Stock Market". American Journal of Business and Managementi. Vol. 3 (2). Hlm. 77- 94.

Maslichah, N. D, Adhikara, A. (2014). Manfaat Informasi Akuntansi Dalam Intensi Pemilihan Saham Di Bursa Efek Indonesia. SNA 17 Mataram, Lombok 24- 27 September 2014.

Masrurun, I. dan Yanto, H. (2015). Determinan Perilaku Investor Individu Dalam Pengambilan Keputusan Investasi Saham. Accounting Analysis Journal. ISSN 2252-6765.

Nababan, D. dan Sadalia, I. (2013). Analisis Personal Financial Literacy dan Financial Behavior Mahasiswa Srata I Fakultas Ekonomi Universitas Sumatera Utara. Diakses 1 Agustus 2019 http://repository.usu.ac.id/handle

Nofsinger, J. R. (2005). The Psychology of Investing, Pearson Education, Second Ed., NJ: UpperSaddleRive

Puspitaningtyas, Z. (2010). Decision Usefulness Approach of Accounting Information: Bagaimana Informasi Akuntansi menjadi Useful?. AKRUAL: Jurnal Akuntansi, Vol. 2, No. 1, hal. 85-100.

Setyani, U. (2007). Hubungan antara konsep diri dengan intensi mencontek pada siswa sma negeri 2 semarang. Program Studi Psikologi Fakultas Kedokteran. Universitas Diponegoro. Semarang

Sugiyono. (2017). Metode Penelitian (Pendekatan Kualitatif, Kuantitatif, dan R\&D). Bandung: Alfabeta.

Sukirno, R. S. H. dan Sutarmanto, H. (2007). Faktor-faktor yang mempengaruhi intensi membeli produk wayang kulit pada masyarakat suku Jawa. Psikologika, 24, 119-131.

Tung, L. C. (2011). The Impact of Entrepreneurship Education on Entrepreneurial Intention of Engineering Students. City University of Hongkong: Run Run Shaw Library. 